NIST Technical Note 1748

\title{
Framework for Addressing the National Wildland Urban Interface Fire Problem - Determining Fire and Ember Exposure Zones using a WUI Hazard Scale
}

Alexander Maranghides William Mell

http://dx.doi.org/10.6028/NIST.TN.1748

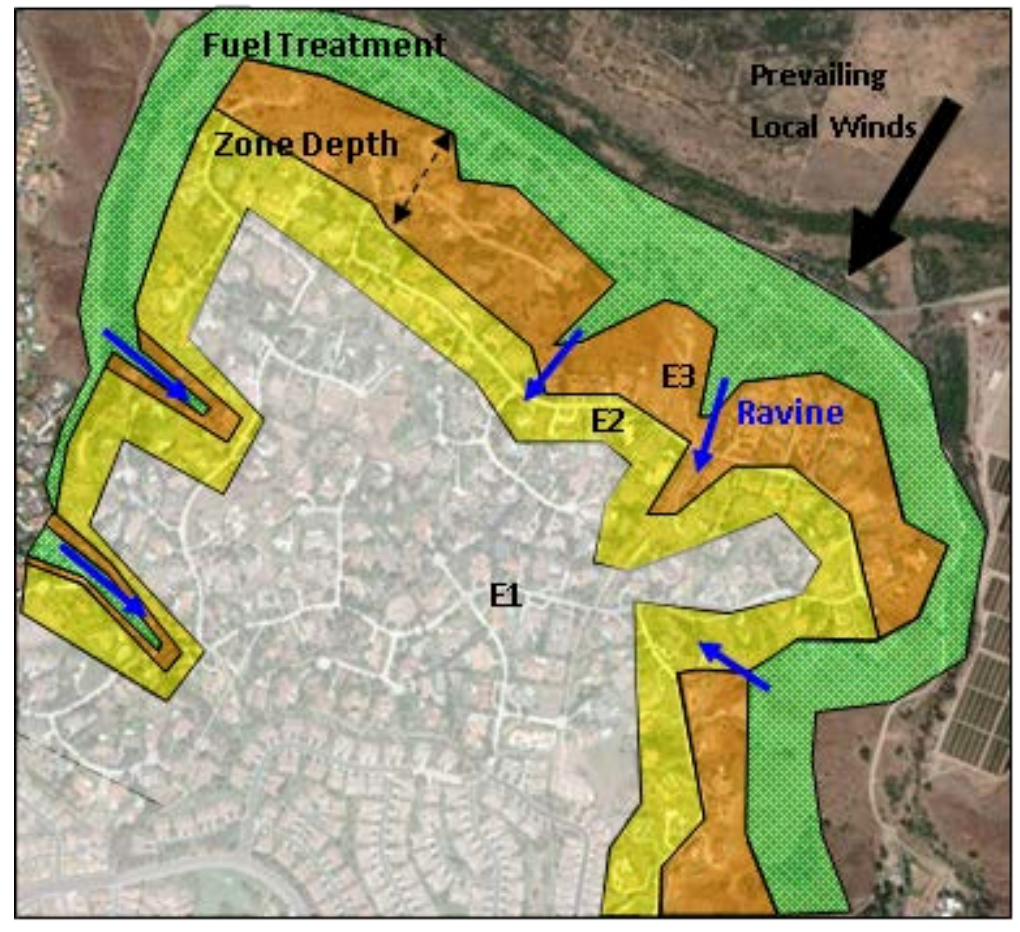

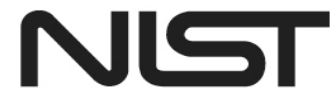

National Institute of Standards and Technology U.S. Department of Commerce 
NIST Technical Note 1748

\section{Framework for Addressing the National Wildland Urban Interface Fire Problem - Determining Fire and Ember Exposure Zones using a WUI Hazard Scale}

Alexander Maranghides Engineering Laboratory Fire Research Division

William Mell U.S. Forest Service Fire and Environmental Research Applications Team Pacific Northwest Research Station Seattle, WA 98103 http://dx.doi.org/10.6028/NIST.TN.1748

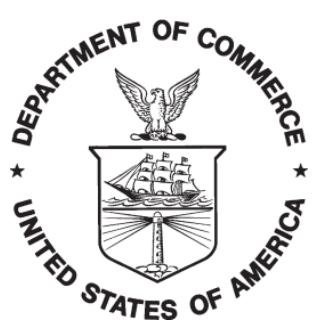

U.S. Department of Commerce Rebecca Blank, Acting Secretary

National Institute of Standards and Technology Patrick D. Gallagher, Under Secretary of Commerce for Standards and Technology and Director 
Certain commercial entities, equipment, or materials may be identified in this document in order to describe an experimental procedure or concept adequately. Such identification is not intended to imply recommendation or endorsement by the National Institute of Standards and Technology, nor is it intended to imply that the entities, materials, or equipment are necessarily the best available for the purpose.

National Institute of Standards and Technology Technical Note 1748 Natl. Inst. Stand. Technol. Technical Note 1748, 25 pages (January 2013)

This publication was a joint effort between the National Institute of Standards and Technology and the United States Forest Service (USFS). 


\section{Table of Contents}

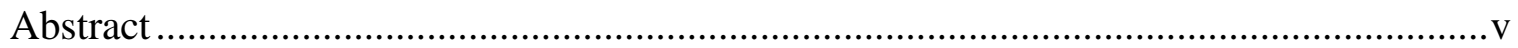

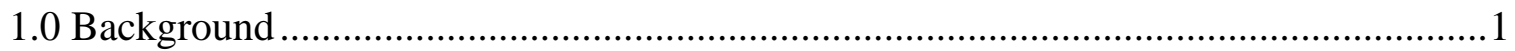

2.0 Overview ........................................................................................................ 1

3.0 Current WUI Building Codes and Standards Practices ..............................................2

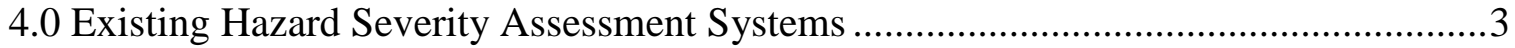

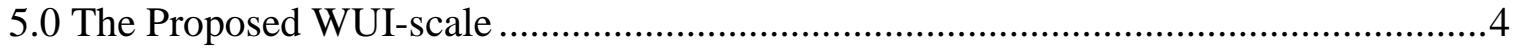

5.1. The Fire and Ember Exposure Scales ............................................................6

5.2. Technical Assumptions ..................................................................................... 7

5.3. Fire and ember exposure from fire in wildland fuels........................................ 7

5.3.1. Wildland Ember Exposure Zones ...............................................................9

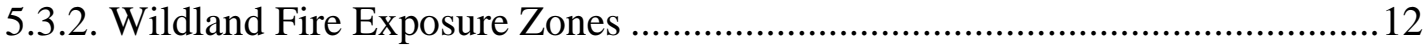

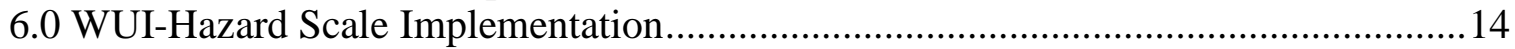

6.1. Building Construction Attributes and Landscaping for Protection against Embers

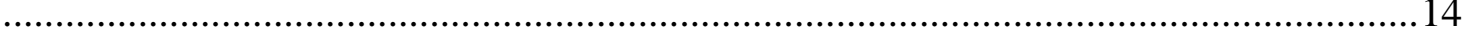

6.2. Building Construction and Landscaping Attributes for Protection against Fire.....14

6.3. Improving WUI Building Codes and Standards .............................................17

6.4. Special Implementation Considerations ..........................................................17

6.5. Designing a New Community Using the WUI-Hazard Scale................................17

6.6. Evaluating an Existing Community Using the WUI-hazard scale.........................18

6.7. Post Fire Community Reconstruction/Rebuilding .............................................19

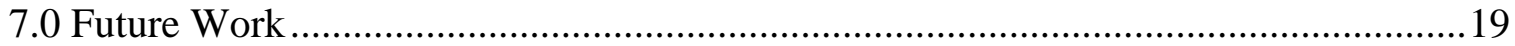

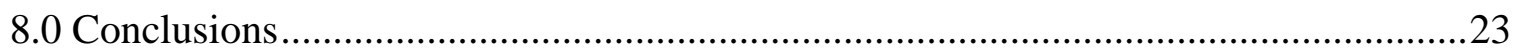

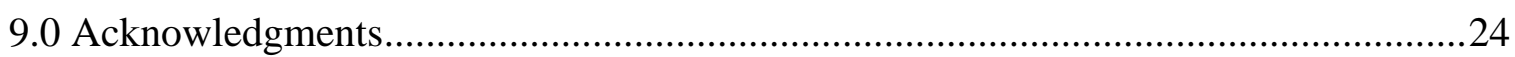

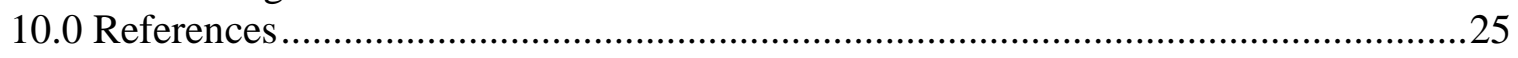




\section{List of Tables}

Table 1: Building Element Vulnerability to Ember and Fire Exposure............................... 5

Table 2: Fuels and Fire/Ember Exposures to Structures................................................ 6

Table 3: Representative Ember Zone (E-zone) Fuel, Terrain and Local Weather............. 10

Table 4: E-Scale Building Construction Classes and Attributes ..................................... 15

Table 5: Fire and Ember Exposures and Threat to Homeowners and Fire Fighters.......... 16

Table 6: WUI-scale Framework Summary .................................................................. 21 


\section{List of Figures}

Figure 1: Primary Fuels Responsible for Fire and Ember Exposure at the WUI ............... 5

Figure 2: Capturing Exposure from Wildland Fuels.................................................... 8

Figure 3: Ember Exposure from Wildland Fuels Matrix .............................................. 9

Figure 4: Illustration of wildland ember exposure on community ................................. 11

Figure 5: Community illustration of wildland fire exposure .......................................... 13

Figure 6: Reducing WUI building Losses; Coupling Ember Exposure to Building

Construction and Landscaping Classes ...................................................... 14

Figure 7: Defensive Actions - reducing exposure and/or reducing ignition vulnerability 16

Figure 8: Illustration of wildland ember exposure on community surrounded fuel

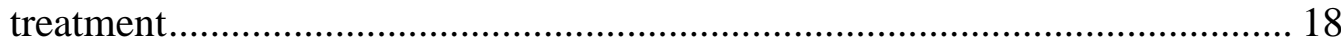

Figure 9: Technical framework for developing the WUI Hazard Scale ........................... 23

Figure 10: Snapshot from a computer simulation, using the Wildland-urban interface Fire Dynamics Simulator (WFDS), ${ }^{18}$ of a WUI fire in Worley, Idaho. Tree locations and heights were obtained from LiDAR data. ............................................... 24 


\title{
Framework for Addressing the National Wildland Urban Interface Fire Problem - Determining Fire and Ember Exposure Zones using a WUI Hazard Scale
}

\author{
By \\ Alexander Maranghides and William Mell
}

\begin{abstract}
Destruction of homes and businesses from Wildland Urban Interface (WUI) fires has been steadily escalating as have the fire suppression costs associated with them. Since 2000, in the United States, over 3,000 homes per year are lost to WUI fires. This is compared to about 900 homes in the 1990s, and 400 homes in the 1970s. In 2011, in Texas alone, over 2,000 homes were destroyed during WUI fires. The WUI fire problem affects both existing communities and new construction. In the U.S, the problem is most acute in the western and southern states; however, WUI fires have also recently destroyed homes in the Mid-Atlantic States and the Pacific Northwest.
\end{abstract}

One of the fundamental issues driving the destruction of homes at the interface is the very limited coupling between building codes and standards and potential fire and ember exposure. The limited exposure information currently available does not address the full range of realistic WUI exposures and offers little context for the design of ignition resistant landscapes and buildings. While the principles of ignition and fire spread at the WUI have been known, actual exposure quantification has been very limited. The resulting gap between exposure and structure ignition has therefore resulted in a lack of tested and implementable hazard mitigation solutions. As an example, there is currently little quantifiable information that links the ember generation from wildland fuels to building assemblies testing.

A WUI fire and ember exposure scale (WUI-scale) needs to be created to help consistently quantify the expected severity of WUI fire events based on measures, or scales, of expected ember and fire exposure. Once established, these technically based ember and fire exposures for the WUI can form the technical foundation for the development of a set of performance based building codes aimed at providing a level of structure ignition protection commensurate with the expected fire and/or ember exposure.

The concept is based on quantifying expected fire and ember exposure throughout an existing WUI community. The proposed WUI-scale can be used to explicitly identify WUI areas that have a fire problem, as opposed to areas that meet housing density or wildland vegetation requirements as is frequently done. The scale can therefore be used to provide the boundaries where specific land use and/or building construction regulations would apply. Finally, the exposure scale can be used for both new and existing WUI communities.

KEY WORDS: Wildland Urban Interface, WUI, fire behavior, fire exposure, ember exposure, WUI exposure scale 


\subsection{Background}

Destruction of homes and businesses from Wildland Urban Interface (WUI) fires have been steadily escalating as have the fire suppression costs associated with them. ${ }^{1}$ Since 2000, in the U.S., over 3,000 homes per year are lost to WUI fires. This is compared to about 900 homes in the 1990s, and 400 homes in the 1970s. ${ }^{\text {i }}$ In 2011, in Texas alone, over 2,000 homes were destroyed during WUI fires. ${ }^{i i}$ The WUI fire problem affects both existing communities and new construction. In the U.S, the problem is most acute in the western and southern states; however, WUI fires recently have destroyed homes in the Mid-Atlantic States and the Pacific Northwest.

WUI fires present a unique challenge to the fire fighting and fire protection engineering communities. The scale of the events can be vast, spanning in many cases over 40,000 ha (100,000 acres). The moving fire perimeter can be tens of kilometers long with potentially thousands of structures at risk. The severity of the fire is dependent on vegetative (wildland and ornamental) and structural fuels, topography, and weather. Compared to hurricanes and earthquakes, fire intensity can vary significantly over relatively short distances (fractions of a kilometer) requiring complex fire suppression and evacuation operations.

There are many WUI definitions based on different attributes including vegetative fuels or population density. In the Federal Registrar "the urban wildland interface community exists where humans and their development meet or intermix with wildland fuel." iii Further WUI sub-characterizations include interface, intermix and occluded type communities. Attempts have been made to characterize the hazard as well as the risk; however, results have been mixed due primarily to the diverse nature of the objectives driving the definitions.

\subsection{Overview}

One of the fundamental issues driving the destruction of homes at the interface is the very limited coupling between building codes and standards and potential fire and ember exposure. The limited exposure information currently available does not address the full range of realistic WUI exposures and offers little context for the design of ignition resistant landscapes and buildings. While the principles of ignition and fire spread at the WUI have been known, actual exposure quantification has not taken place. The resulting gap between exposure and structure ignition therefore has resulted in a lack of tested and implementable hazard mitigation solutions.

A WUI fire and ember exposure scale (WUI-scale) needs to be created to help consistently quantify the expected severity of WUI fire events based on measures, or scales, of expected ember and fire exposure. Once established, these technically based ember and fire exposures for the WUI can form the technical foundation for a set of performance based building codes aimed at providing a level of structure ignition protection commensurate with the expected fire and/or ember exposure. 
The concept is based on quantifying expected fire and ember exposure throughout an existing WUI community. The proposed WUI-scale can be used to explicitly identify WUI areas that have a fire problem, as opposed to areas that meet housing density or wildland vegetation requirements. The scale therefore can be used to provide the boundaries where specific land use and/or building construction regulations would apply. Lastly, the exposure scale can be used for both new and existing WUI communities.

\subsection{Current WUI Building Codes and Standards Practices}

WUI building construction is influenced by codes and standards developed from the cumulative expertise and experience of the participating committee members. This includes the evaluation of structural performance during past WUI fires, limited laboratory work, and very limited WUI fire modeling. WUI post-fire assessments consider structural performance, and if conducted systematically, should be used as part of a comprehensive approach that includes laboratory and full scale experiments as well as computer modeling to guide and confirm the effectiveness of changes to buildings codes, standards and best practices. To date, post-fire WUI field data collections ${ }^{\text {iv,v }}$ have failed to address three critical components:

\section{Impact of Defensive Actions}

The influences of defensive actions are typically not considered. This critical information can be collected post-event through discussions with the first responders and homeowners, albeit with significant effort. Certain defensive actions taken by fire fighters, police, home owners or others are readily apparent to the trained first responder conducting a post-fire study. Many times, however, information on defensive actions is lost and, as a result, structure survivability can be misinterpreted. For example, the initial information collected within The Trails community in San Diego, after the 2007 Witch/Guejito fires, suggested that very limited defensive actions occurred within the community. Subsequently, more comprehensive data collection and discussions with homeowners and first responders determined that one out of every three structures in that community had been defended. Without this information on defensive actions, a complete assessment of the relevant factors underlying the survivability of structures could not be assessed. ${ }^{\text {vi }}$

\section{2. $\quad$ Systematic Documentation of Structure Response to WUI Fires}

Second, until recently, a systematic method for documenting structure response and exposure, throughout the area exposed to a WUI fire, has not been developed or applied. A systematic approach of documenting all the structures within the fire perimeter, or a community of interest, will support a significantly more reliable assessment of structure ignition vulnerabilities. Documenting only destroyed and damaged structures can result in erroneous data interpretation with respect to structural ignitions. Here is an example: at The Trails community in San Diego, CA, the Witch/Guejito fires in 2007 destroyed 74 homes and damaged 16. Out of the 74 destroyed homes, 12 had wood shake roofs (of varying ages and treatments), while 37 had Spanish tile roofs (with and without bird stops), 24 had composite roofs, and there was one metal roof. The wood shake roofs accounted for $16 \%$ of the destroyed structures, while the Spanish tile roofs were $50 \%$ of the destroyed structures. There were a total of 245 structures within the fire at The 
Trails. Considering the performance of all roofs within the fireline, $100 \%$ of the wood shake roofs exposed were destroyed while only $24 \%$ of Spanish tile roofs were destroyed. By documenting all structures within the fire line, the relatively high (all other factors being equal) vulnerability of wood shake roofs stands out. This baseline comparison is critical to understanding the true impact of different construction and landscaping attributes to structure survivability. While quantifying structure survivability is a complex process that involves construction particulars and measures of fire and ember exposure, the above example illustrates how misleading partial information can be.

\section{Quantification of Fire and Ember Exposure}

There is a lack of consistently applied measures to characterize fire and ember exposures during WUI fire events. This is one of the key constraints to improving the understanding of structure survivability and is essential to the development and assessment of implementable national WUI hazard reduction methodologies. A common yardstick for exposure will enable reliable comparison of the relative performance of different hazard reduction solutions. The response of a structure exposed to a severe ember assault cannot be compared to the response of a structure that experienced only a minor ember attack. Only by using a common yardstick of exposure can comparisons be made within and across different WUI fire incidents.

\subsection{Existing Hazard Severity Assessment Systems}

An example of an existing community-scale hazard severity assessment program is the one developed by California Department of Forestry and Fire Protection (CAL FIRE). The CAL FIRE and Resource Assessment Program (FRAP) Fire Hazard Severity Zones ${ }^{4}$ is used to determine fire hazard on a $9 \mathrm{~m}$ (30 ft) grid. This information is applied in areas under State jurisdiction. The assessment was done for all of California and was used by the State Responsibility Areas (SRA) for stricter requirements and provide an avenue for Local Responsibility Areas (LRA) to use stricter construction for new construction) to identify where the stricter California ${ }^{\text {vii }}$ WUI construction building code are required for new construction. The FRAP Fire Hazard Severity Zones are geographical areas designated pursuant to California Public Resources Codes Sections 4201 through 4204 and classified as Very High, High, or Moderate in State Responsibility Areas, or as Local Agency Very High Fire Hazard Severity Zones designated pursuant to California Government Code, Sections 51175 through 51189.”viii The FRAP program is one of the few programs in the U.S. that links fire severity (exposure) and building codes (construction attributes). While the FRAP program links expected exposure to specific building code requirements, its classification system focuses primarily on proximity to wildland fuels and does not address the likelihood that buildings could be destroyed due to other fire and ember exposures such as from an adjacent burning structure. The FRAP system, with respect to building construction is two tiered: a structure is either in the WUI or it is not. This exposure classification system looks at wildland exposure as bimodal and does not address the likelihood that buildings could be destroyed from exposure sources other than from the wildlands. Other similar programs, but less complex WUI hazard rating systems exist and are implemented across the U.S. 
The Home Ignition Zone (HIZ) ${ }^{\mathrm{ix}}$ concept represents another WUI hazard severity assessment framework designed to be implemented at a parcel or structure level. The home ignition zone includes the home and an area surrounding the home within 100 to 200 feet (30 to $60 \mathrm{~m}$ ). The method has been successfully used to educate homeowners on the different parameters affecting structure survivability. The primary limitation of the HIZ methodology in the context of this paper is that it does not offer a framework to link the fire and ember exposure threat to building codes and standards. An additional limitation of the HIZ system is that it does not account for different exposure scenarios. A framework similar to the HIZ is also used by the International Wildland-Urban Interface $\operatorname{Code}^{\mathrm{x}}$ as well as many other national and state hazard mitigation programs.

As mentioned earlier, it should be pointed out that, to date, WUI hazard assessment tools have generally not been developed using the results from a systematic and standardized field data collection methodology. This uncoupled approach limits the reliability of these tools as there has been no framework for coupling field exposure data to structure survivability. Additionally, there has been no coupling between ember/fire exposure and first responder and homeowner safety.

\subsection{The Proposed WUI-scale}

WUI fire events, unlike other natural disasters such as hurricanes, tornadoes and earthquakes, do not weaken with distance away from a well defined epicenter. Fire behavior in the wildlands and the WUI is a function of fuel (vegetative and structural), topography and local weather during the event. A fire and ember exposure driven WUI scale, therefore, needs to account for local and transient variations in fuel, topography and local weather. Using such a rating, an overall WUI area may receive a range of ratings. The ratings will reflect the potential severity of a WUI fire event at specific locations. This paper outlines the technical foundation for the creation of a WUI fire and ember exposure scale as well as a framework for linking the proposed scale to national WUI building codes and standards.

The WUI-scale is designed to quantify fire and ember exposure in the WUI over the range of fire and ember exposure conditions experienced by structures at the WUI. Fire and ember exposure can be traced to four primary sources: wildland fuels, ornamental vegetation and burning of structures (including homes, auxiliary buildings such as sheds and garages) and vehicles (figure 1). The WUI-scale is designed considering these sources as well as the local weather. These combined parameters are referred to as FTLW, short for fuels, topography, and local weather ${ }^{1}$. In the proposed framework, an exposure rating is uncoupled from ignition, and the exposure rating is independent of the response of a particular structural element or landscaping attribute.

The proposed WUI-scale is developed with the primary objective of reducing the ignition risk of buildings in the WUI. This will be accomplished by linking the ignition resistance required of structures to anticipated exposures by using the exposure scale. During a WUI fire, a given structure can be exposed to fire and/or embers. Both threats

\footnotetext{
${ }^{1}$ Local weather here refers to local wind speed, wind direction, temperature and relative humidity.
} 
need to be independently quantified and addressed. A structure can be hardened for embers, fire, or both. Table 1 is used to illustrate how three distinct building elements may be vulnerable to exposure from embers and/or fire.

Table 1: Building Element Vulnerability to Ember and Fire Exposure

\begin{tabular}{|c|c|c|}
\hline \multirow{2}{*}{ Building Elements } & \multicolumn{2}{|c|}{ Potential Ignition Vulnerability } \\
\cline { 2 - 3 } & Embers & Direct Fire \\
\hline Metal Frame Closed Window & No & Yes $^{2}$ \\
\hline Untreated Wooden Deck & Yes & Yes \\
\hline Attic Insulation & Yes $^{3}$ & No \\
\hline
\end{tabular}

The approach outlined in the text below offers a qualitative framework for establishing a WUI-scale. Two issues must be dealt with to make the scale quantitative: the critical lack of quantitative information on the exposure of structures to embers and fire; and the lack of a well characterized, systematic effort that combines pre- and post-fire observations, laboratory and field experiments, and fire modeling. An exposure and structure response database is required to successfully develop the WUI-scale approach. An explicit technical plan to meet these needs has been outlined in the paper by Mell et al. ${ }^{\text {xi }}$ The technical plan to be followed is summarized and presented here in the last section of the current paper.

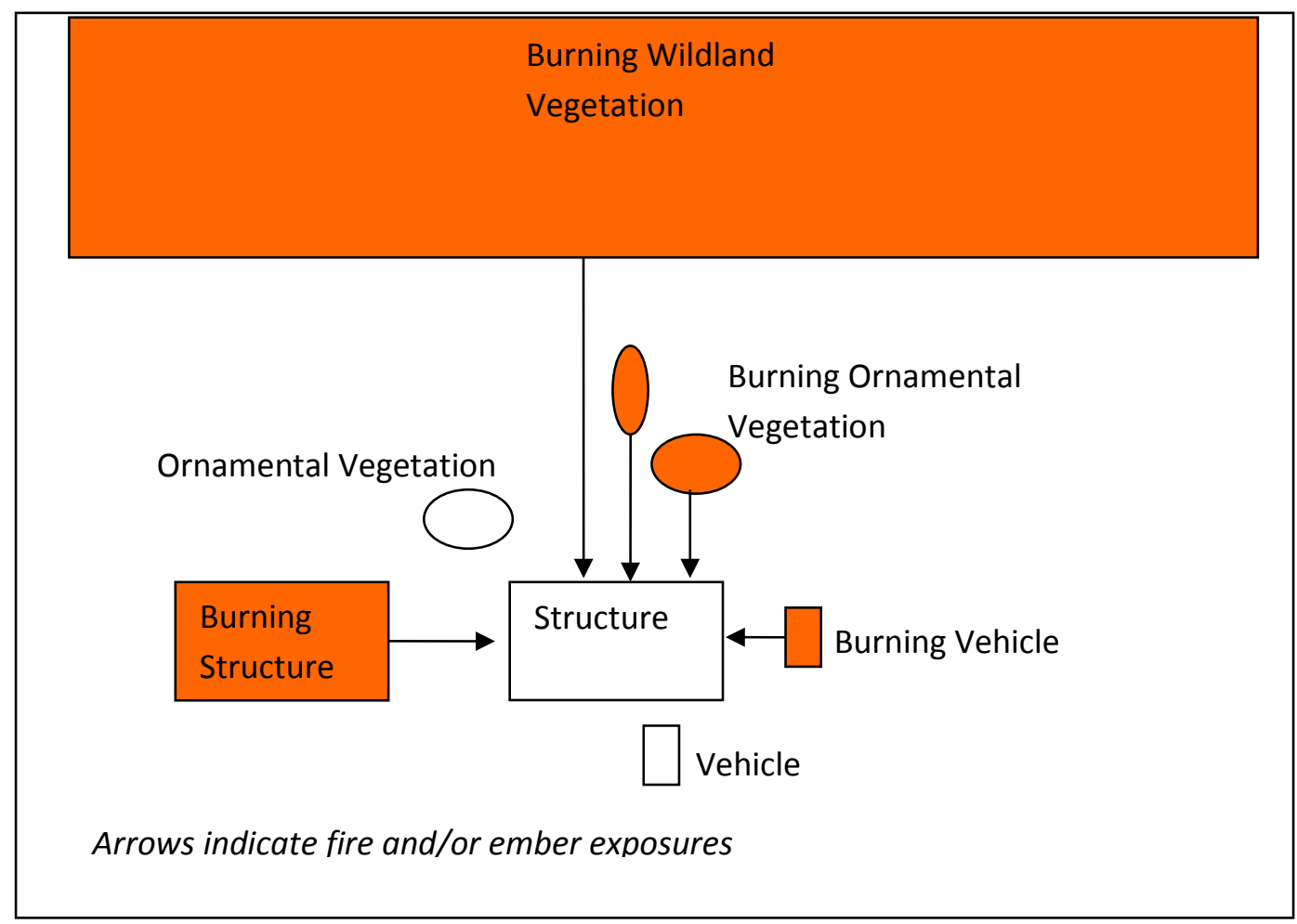

Figure 1: Primary Fuels Responsible for Fire and Ember Exposure at the WUI

\footnotetext{
${ }^{2}$ Window may break under direct flame exposure.

${ }^{3}$ Combustible insulation may ignite from embers inside attic, away from exterior attic vents
} 
Unlike a hurricane that gets an overall rating based on maximum sustained winds, a WUI fire, being so dynamic and variable in space and time, cannot be characterized by a single rating. The proposed scale uses the local conditions that create the fire and embers to generate a local exposure or rating. In this context, the proposed scale may be used for a particular community to rank the threat from the wildlands. A wildland fire may present a higher threat to one community compared to another based on the wildland fuels throughout the interface, local winds, and topographic features. The scale is designed to work along the interface and nominally $1.2 \mathrm{~km}$ ( 0.75 mile) into the community from the perimeter. $^{4}$

Another distinction between a hurricane (or other natural hazard) and a WUI fire is that the hazard level of a fire may be mitigated ahead of time through fuel removal. The proposed methodology can provide the science to enable benefit-cost analysis on the extent of implementation of fuel removal or treatments for specific fuel, topographical and weather conditions. The ecological and environmental impacts of such treatments are beyond the scope of this document.

\subsection{The Fire and Ember Exposure Scales}

In the WUI-scale approach, the fire and ember exposure threats each can be binned in different categories. The intensity of the exposure increases from category 1 to 4 and the exposure levels decrease with distance away from the burning source. When applied in practice, both ember and fire exposure levels need to be used to capture the total threat to a structure. Additionally, both need to be accounted for when hardening a structure against ignition.

This two component (fire and ember) exposure scale is necessary as these two exposures threats have different origins, each with a different "reach." The radiative heat flux generated by a fire decays with the square of distance away from the flame front and is mainly affected by the fuels in the immediate vicinity of the fire. ${ }^{5,6}$ The embers, on the other hand, can travel hundreds of meters or more.

Embers from far afield may pose a threat to a particular structure even if the same fire creating these embers is not exposing the structure to the fire heat. Table 2 illustrates how different fuels and their proximity to a target structure contribute to both the fire and ember exposure scale.

Table 2: Fuels and Fire/Ember Exposures to Structures

\begin{tabular}{|c|c|c|}
\hline Burning Fuel & Fire Exposure & Ember Exposure \\
\hline Vegetation near structure & Yes & Yes \\
\hline Nearby wildland vegetation & Yes & Yes \\
\hline
\end{tabular}

\footnotetext{
${ }^{4}$ This value may be refined as additional post-fire data collection and analyses are conducted using a systematic method for documenting exposure, defensive actions and structural behavior.

${ }^{5}$ Convective heating is also included in the determination of the fire exposure.

${ }^{6}$ Well irrigated, low flammability vegetation near a structure can block radiation from an approaching fire.
} 


\begin{tabular}{|c|c|c|}
\hline Distant wildland vegetation & No & Yes \\
\hline Nearby structure & Yes & Yes \\
\hline Distant structure & No & Yes \\
\hline
\end{tabular}

Extensive quantification is necessary both for the fire and ember exposures. The proposed exposure scales offer a framework to initiate the implementation of this concept. Quantification of the fire and ember exposures could be achieved through a combination of post fire studies, laboratory and field experiments, and computer modeling. $^{11}$

A community may include one or more areas or zones of a given exposure level. Any one location in the community will have both a fire and an ember exposure rating. As an example, a location could have no fire exposure, yet have an intermediate ember exposure.

\subsection{Technical Assumptions}

The following assumptions are used in the development of the WUI-scale:

1. The fire and ember exposure conditions at a given location can originate from fire in wildland fuels and fuels within the WUI community. The fire and ember exposure each zone experiences are the linearly combined exposures of the external and internally generated exposures. As an example, structures within a zone will experience a significant ember assault from its proximity to wildland fuels, and from any burning fuels within the zone itself.

2. During a WUI fire, both the fire exposure and ember assault at a given location will change with time. The fire and ember scales are intended to capture both the peak intensity and maximum duration of the exposure/assault.

The distance from the interface and width of each zone will be a function of fuel, topography and local weather (FTLW). The four zones selected for each of the fire and ember exposures are described below specifically as to exposure from the wildlands.

\subsection{Fire and ember exposure from fire in wildland fuels}

Wildland fire and ember exposures in very high risk areas can result in significant structural losses at the perimeter of many communities. Field observations from first responders have identified burning homes as large ember generators, posing a significant threat to surrounding and particularly downwind structures and vegetation. By preventing the ignition of structures in very hazardous locations, significant reductions in further fire spread are achievable within WUI communities.

The proposed approach will therefore initially focus on wildland fire and ember exposure from the wildlands. Fire and ember exposure from burning structures, ornamental vegetation or vehicles will be considered at a latter date following the same framework. This exposure framework, together with the supporting updates to building codes and standards, will make the WUI-scale directly applicable to new construction. Additionally, the current approach will enable the WUI-scale to be used for evaluating existing communities, highlighting weaknesses and identifying retrofit solutions. Figure 2 
illustrates the fire and ember exposure matrix for wildland fuels. The proposed exposure matrix is developed using three categories for terrain: flat, steep slope and ravine; and three categories for wind: no wind, low and high wind. Four fuel categories will be used to provide initial matrix characterization: homogeneous surface fuels (such as prairie grasses), inhomogeneous surface fuels (such as palmetto), inhomogeneous shrubs and low vegetation (such as chaparral), and canopied forest (such as what is found in the intermountain west). The selected topographical, weather and fuel attributes, while not all encompassing, provide realistic input ranges for the characterization of fire and ember exposures. Modeling and field data collection from prescribed burns will be used to define the specifics of the topography, weather and fuel attributes.

A similar type of matrix will provide, in the future, the fire and ember exposure from burning structures, ornamental vegetation, and vehicles in different local weather and topographical conditions. The approach is designed to quantify the fire and ember exposure (Figure 2) and, together with improved building codes and standards, support the design and maintenance guidelines of ignition resistant structures. Figure 3 illustrates the ember exposure from various wildland fuels. Certain wildland fuels, under certain conditions may generate severe ember exposures to a target, while under different conditions they may generate significantly lower exposures.

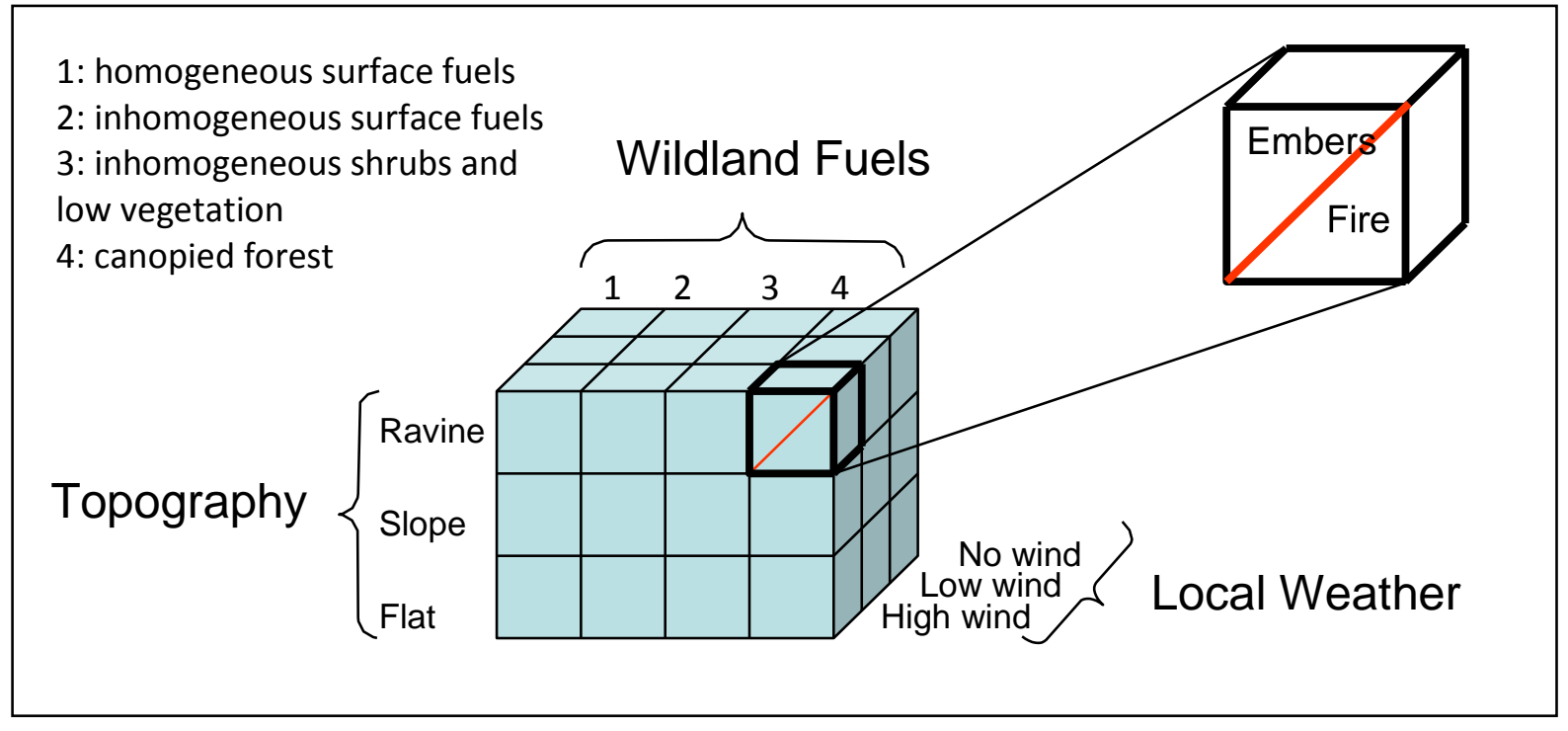

Figure 2: Capturing Exposure from Wildland Fuels 


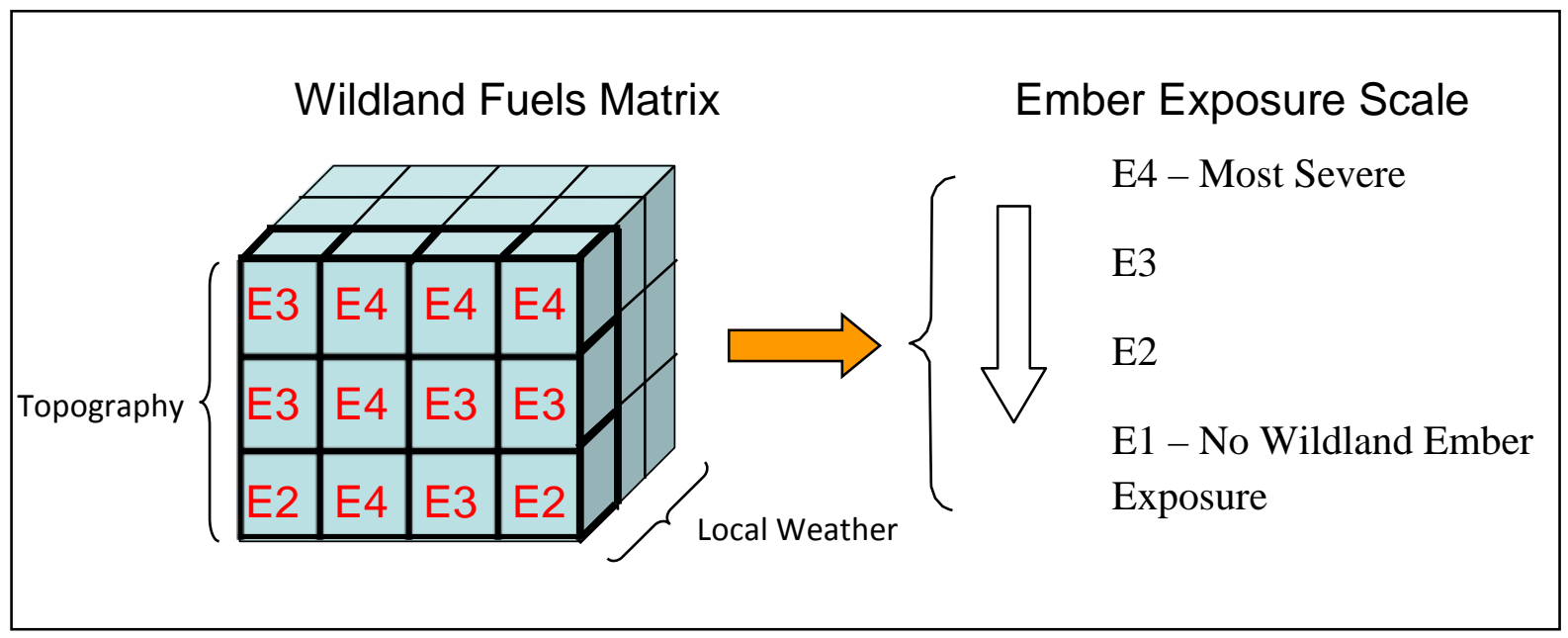

Figure 3: Ember Exposure from Wildland Fuels Matrix

\subsubsection{Wildland Ember Exposure Zones}

Ember flux data are needed to characterize the ignition of both structural elements and vegetation and to specify the four proposed ember zones as follows:

E1: The first ember zone, E1 is defined as having no significant flux of embers (in grams $/ \mathrm{m}^{2}$-sec). ${ }^{7}$

E2: The second ember zone, E2, is defined as one where there is a low ember assault. This area or band typically in the interior of the community will offer improved protection from a direct wildfire assault. Ember flux data is not currently available.

E3: This ember zone is typically found on the perimeter of the community and close to or adjacent to wildlands. This zone will experience a significant ember assault. Ember flux data is not currently available; experiments are needed to characterize the ignition of structures and structural elements as a function ember mass flux.

E4: This ember zone is found on the perimeter of the community and will be subject to extreme ember exposure. As an example, the area around terrain features such as a chimney or ravine may be classified as E-4 if the wildland fuel load is significant and low humidity and high local winds are present or expected. E-4 is typically found at the interface between wildland and residential fuels. E-4 may extend into the community based on topographical and fuel features.

Guidelines for the WUI-scale determination are summarized in Table 3 for embers. In conducting a WUI-scale evaluation, the fuel is evaluated followed by terrain and local weather. The fuel drives the overall evaluation, since if fuel is not present, the hazard is dramatically reduced. Fuel is a critical but not sufficient part of characterizing the exposure. After the fuel had been characterized, terrain and local weather must be

\footnotetext{
${ }^{7}$ The mass and type (e.g. size) of embers contribute to its potential to contribute to the ignition of combustibles. The mass flux is used as a simplified way to quantify exposure. Additional research is needed on the attributes of embers being generated by burning wildland and ornamental vegetation as well as by burning structures.
} 
assessed before the WUI-scale can be determined for a particular locale. While the presence of fuel is a key component to determining the ember exposure, it is the combination of fuel, topography and local weather that is responsible for the final ember exposure. Table 4 contains representative fuel, terrain and local weather conditions that are expected to yield different ember fluxes and E-scale ratings.

The WUI-scale concept is multi-threat and exposure driven and therefore other combinations may result in similar exposures. All three columns represent maximum attribute characteristics for each zone. For instance, the local weather can be identified as the worst case scenario during the local fire season. While Table 3 represents in general terms four different ember exposures and their associated fuel, terrain and local weather characteristics, modeling and field experiments will be used to populate the table with variations of the above characteristics. As an example, light fuel loading in steep terrain with low humidity and strong winds may generate a significant ember exposure for structure ignition.

\section{Table 3: Representative Ember Zone (E-zone) Fuel, Terrain and Local Weather Characteristics}

\begin{tabular}{|c|l|l|l|l|}
\hline E-Zone & $\begin{array}{l}\text { Ember } \\
\text { Exposure }\end{array}$ & Fuel (necessary) & Terrain & Local Weather \\
\hline E1 & $\begin{array}{l}\text { no ember } \\
\text { exposure }\end{array}$ & $\begin{array}{l}\text { light fuels- wet } \\
\text { environment }\end{array}$ & flat terrain & $\begin{array}{l}\text { - low or moderate } \\
\text { humidity } \\
\text { - light winds }\end{array}$ \\
\hline E2 & $\begin{array}{l}\text { minimal } \\
\text { ember exposure }\end{array}$ & light fuel loading & $\begin{array}{l}\text { moderate } \\
\text { slope }\end{array}$ & $\begin{array}{l}\text { - low humidity } \\
\text { - intermediate winds }\end{array}$ \\
\hline E3 & $\begin{array}{l}\text { significant ember } \\
\text { exposure }\end{array}$ & $\begin{array}{l}\text { intermediate fuel } \\
\text { loading }\end{array}$ & $\begin{array}{l}\text { moderate } \\
\text { slope }\end{array}$ & $\begin{array}{l}\text { - low humidity } \\
\text { - strong winds }\end{array}$ \\
\hline E4 & $\begin{array}{l}\text { extensive ember } \\
\text { exposure }\end{array}$ & $\begin{array}{l}\text { - dry flash } \\
\text { - high fuel loading }\end{array}$ & $\begin{array}{l}\text { - steep slope } \\
\text { - chimneys }\end{array}$ & $\begin{array}{l}\text { - low humidity } \\
\text { - strong winds }\end{array}$ \\
\hline
\end{tabular}

Figure 4 illustrates ember exposure zones within a community from wildland fuel generated embers. The ember generation is a function of fuel, topography and local weather (lining up of topographical features with the prevailing local wind). The different ember exposure intensities are illustrated by differing colors in Figure 4. In the case illustrated, the presence of large quantities of volatile wildland fuels around the community together with steep terrain and the likely presence of high winds resulted in severe ember exposure (E4-dark red) at several locations on the perimeter of the community. At one location where a ravine is lined up with the prevailing wind, E4

\footnotetext{
${ }^{8}$ Flash Fuels: Fuels such as grass, leaves, draped pine needles, fern, tree moss and some kinds of slash, that ignite readily and are consumed rapidly when dry. Also called fine fuels. Source: Glossary of Wildland Fire Terminology, National Wildfire Coordinating Group, PMS 205, October 2006
} 
reaches further into the community. In this case, combinations of fuel and topography, or fuel and prevailing wind are present, resulting in significant ember exposure (E3orange). Further away from the wildlands, the E-2 areas (yellow) represent low ember exposure from the wildlands. Finally, E-1 (white) illustrates the area in the community when no embers from the wildlands are expected. The represented community is on a knoll with an E3 area almost encircling the community. The actual extent of the different exposure areas is provided for illustration only. Specifics of the different ember and fire exposure areas or zones follow. It should be noted that the ember exposure zones are intended to capture or represent the majority of the embers generated. Embers have been known to travel for many kilometers and these far field embers can cause ignitions. In the context of the WUI communities discussed in this paper these limited far field embers are not considered to pose a significant exposure issue when compared to the near field embers from the burning adjacent wildlands.

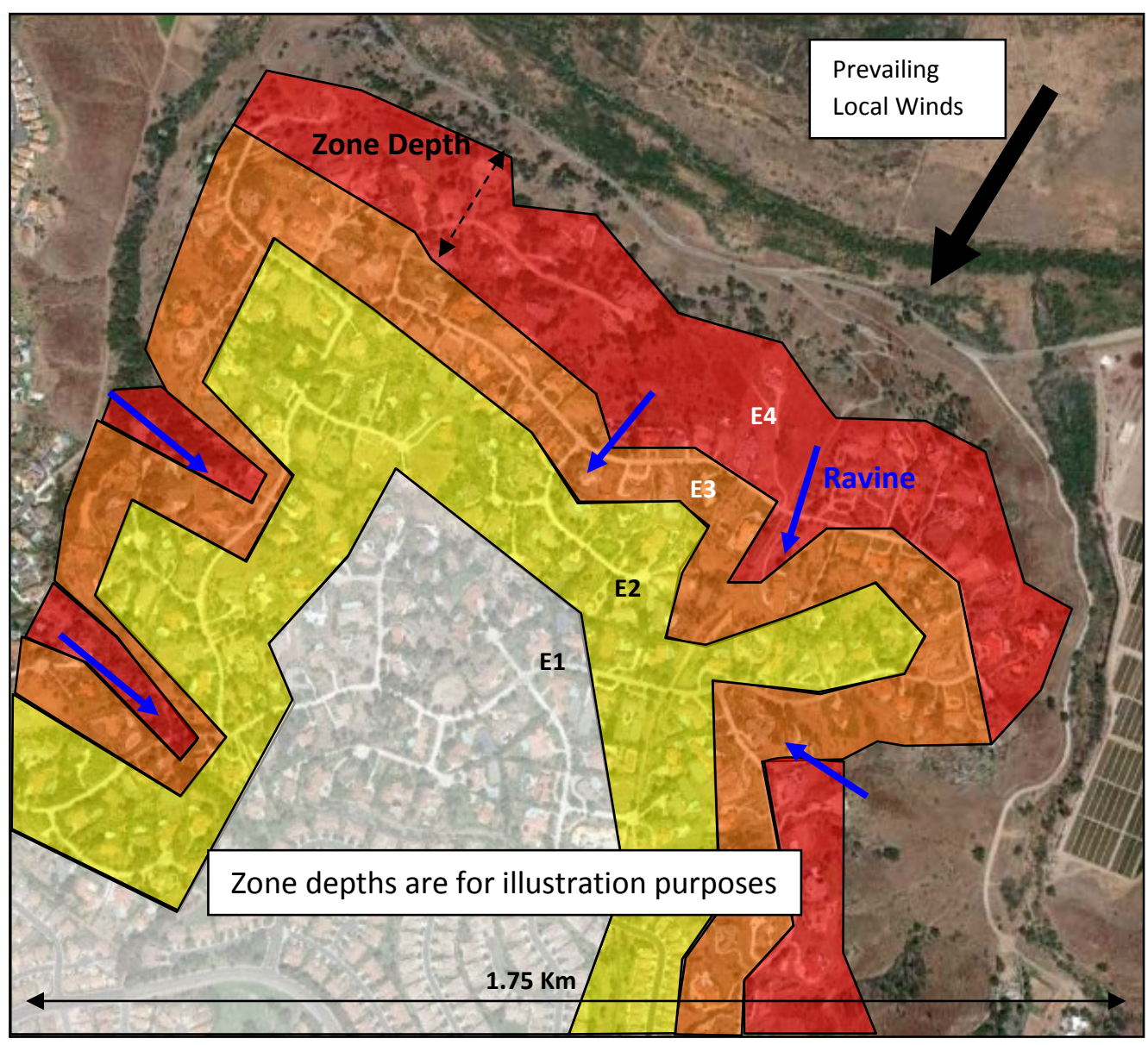

Figure 4: Illustration of wildland ember exposure on community 


\subsubsection{Wildland Fire Exposure Zones}

The following Fire Exposure Zones (F-zone) are proposed to indicate the increasing susceptibility of structures within the community to radiative ignition from the fire flames (as opposed to the embers):

F1: The first F-zone is defined as having no significant heat flux from burning wildland vegetation. No special WUI fire exposure building construction is recommended in this area. There is no expected external heat flux above ambient level.

F2: The second fire zone, F2, is defined as one where there is low heat flux exposure. This area or band typically in the interior of the community will offer improved protection from a direct wildfire assault. Intermediate construction requirements are recommended in the F2 zone. Exposed combustibles are permitted on the structure itself. Combustibles may also be attached to the structure. The incident heat flux can cause harm to humans. No window breakage or ignition of exterior combustibles is likely to occur in Zone 2. Expected heat fluxes above ambient level: up to $0.8 \mathrm{~W} / \mathrm{cm}^{2}$. ${ }^{\mathrm{ii}}$

F3: The third fire zone, F3, is defined as one where there is moderate heat flux. Hardened construction requirements are recommended in the F3 zone with no exposed combustibles on the structure itself. Combustibles may be on the property, a significant distance away from the structure. The incident heat flux can cause harm to humans. Window breakage of unhardened glass and ignition of exterior combustibles will occur in Zone 3. Heat flux levels are expected in the range of 0.8 to $2 \mathrm{~W} / \mathrm{cm}^{2}$. xiii

F4: the fire zone F4 is defined as the area where there is severe heat flux and prolonged direct flame contact. Heat flux level is expected to be greater than 2 $\mathrm{W} / \mathrm{cm}^{2}$.

Determining the extent of the E and F-zones for the different FTLW will be accomplished through the use of computer models, engineering calculations and field experiments. The methodology generates a matrix of community exposure areas or zones (Figures 4 \& 5) based on the most likely worst case scenario for the each of the factors: wildland fuels, weather (specifically local wind and relative humidity) and topography, specifically:

- Wildland fuel build-up is addressed by selecting the steady state fuel loading that can be supported in that particular ecosystem. If fuel treatments are implemented and are part of the long term maintenance of the community surroundings then the loading of the treated fuels should be used in the WUI-Zone determination. ${ }^{9}$

- $\quad$ Local weather conditions are determined from the local weather history.

- Topography should be considered in conjunction with weather, specifically local wind. For example, in Southern California, the Santa Ana wind direction is predictable

\footnotetext{
${ }^{9}$ It should be noted that if a community is built using an exposure rating based on treated wildland fuel loadings, the anticipated hazard reduction will only be achieved if these wildland fuel treatments are maintained. If the fuels treatment is not maintained, the community's ratings will change and building construction and landscaping attributes may no longer provide the resiliency they originally did.
} 


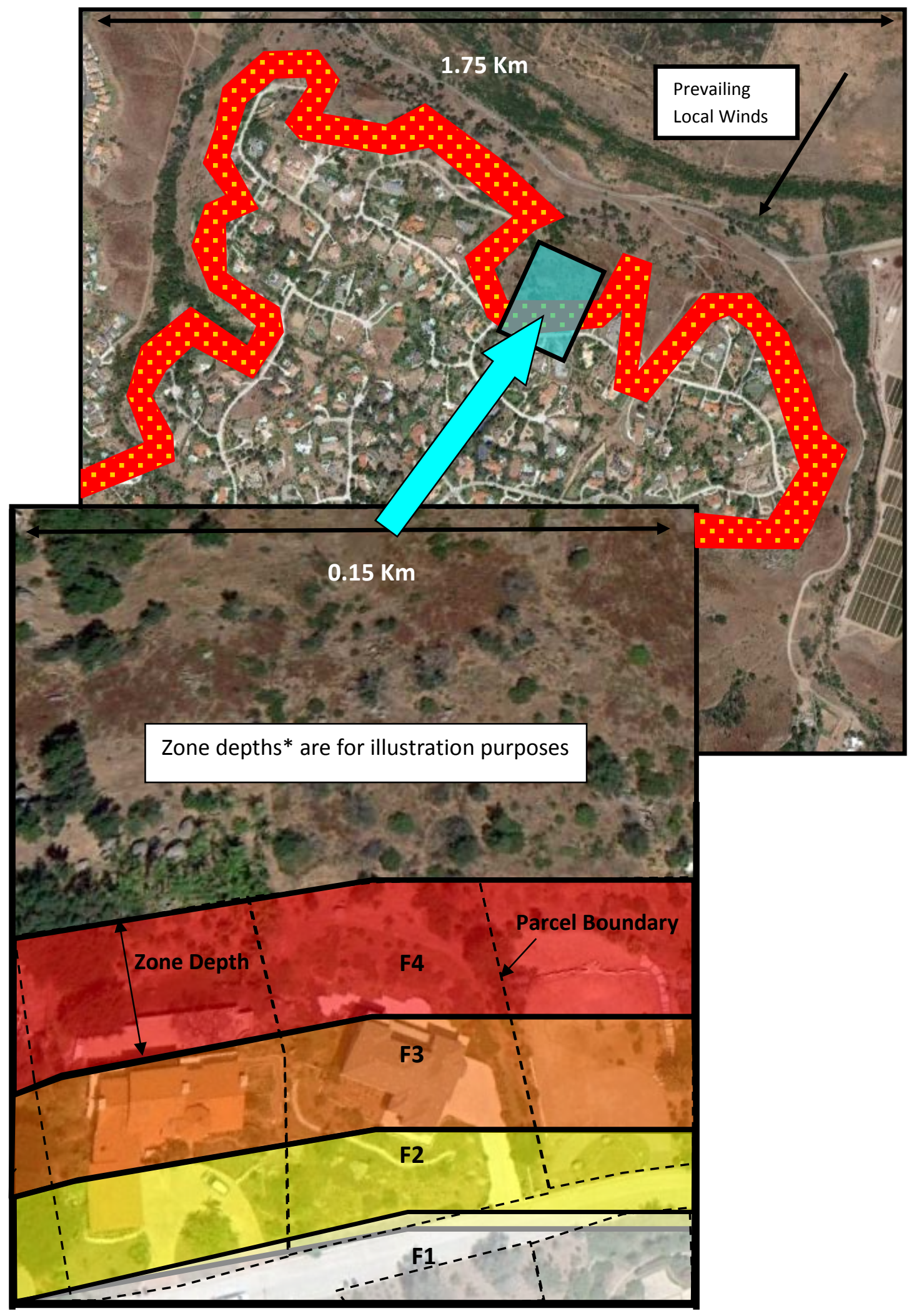

* Zone depths around the community depend on fuels, topography and local weather.

Figure 5: Community illustration of wildland fire exposure 
and well established. Topographical features that line up with the wind flow can result in increased flame lengths and ember transport, increasing the severity of downwind structure exposure conditions.

\subsection{WUI-Hazard Scale Implementation}

In the framework presented here, there are four different WUI building construction and landscaping classes, WUI 1 through WUI 4. The following sections of the paper couple fire and ember exposure ratings to building construction and landscaping attributes.

\subsection{Building Construction Attributes and Landscaping for Protection against Embers}

A WUI community can have up to four different types of structure and landscaping categories based on ember exposure levels as identified by the WUI-hazard scale. Figure 6 outlines the coupling between ember exposure and building construction and landscaping classes. The WUI building construction and landscaping classes and attributes are summarized in Table 4.

\section{Ember Exposure Scale (E-scale) Building Construction and Landscaping Classes \\ E4 - Most Severe

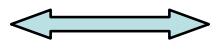 \\ WUI4 - Most Severe \\ E3 \\ E2

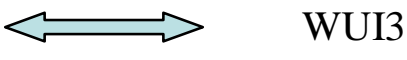 \\ E1

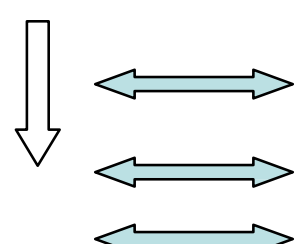 \\ WUI2 \\ WUI1- Unrestricted Construction* \\ * Unrestricted only with respect to WUI exposure}

Figure 6: Reducing WUI building Losses; Coupling Ember Exposure to Building Construction and Landscaping Classes

\subsection{Building Construction and Landscaping Attributes for Protection against Fire}

Defensive actions can be used to reduce ignitions by one of two mechanisms: reduce exposure or reduce vulnerability. Two defensive action examples are provided to illustrate this: pre-wetting a structure reduces its ignition vulnerability, while suppression efforts on the surrounding burning vegetative fuels reduce the structure's exposure to fire and embers (figure 7). The proposed exposure framework, with the associated ember and fire exposure scales can also be used to describe the potential threat to homeowners and firefighters. 
Table 4: E-Scale Building Construction Classes and Attributes

\begin{tabular}{|c|c|c|c|}
\hline $\begin{array}{l}\text { WUI } \\
\text { scale }\end{array}$ & $\begin{array}{l}\text { Building } \\
\text { Construction } \\
\text { Class }\end{array}$ & \begin{tabular}{|l|} 
Ignition \\
Vulnerabilities \\
from Embers \\
and Fire \\
\end{tabular} & $\begin{array}{l}\text { Building Construction and } \\
\text { Landscaping Attributes for } \\
\text { Protection against Embers }\end{array}$ \\
\hline E1 or F1 & WUI 1 & None & $\begin{array}{l}\text { Normal Construction Requirements: } \\
\text { - } \quad \text { Maintained Landscaping } \\
\text { - } \quad \text { Local AHJ-Approved Access for } \\
\text { firefighting equipment }\end{array}$ \\
\hline $\mathrm{E} 2$ or $\mathrm{F} 2$ & WUI 2 & $\begin{array}{l}\text { In this area, highly } \\
\text { volatile fuels could be } \\
\text { ignited by embers. } \\
\text { Weathered, dry } \\
\text { combustibles with } \\
\text { large surface areas can } \\
\text { become targets for } \\
\text { ignition fro m embers. }\end{array}$ & $\begin{array}{ll}\text { Low Construction Hardening Requirements: } \\
\text { - } & \text { Treated combustibles allowed on structure } \\
\text { - } & \text { Attached treated combustibles allowed } \\
\text { - } & \text { Treated combustibles allowed around } \\
& \text { structure } \\
\text { - } & \text { Low flammability plants } \\
\text { - } & \text { Irrigated and well maintained Landscaping } \\
\text { - } & \text { Local AHJ-Approved Access for } \\
& \text { firefighting equipment } \\
\end{array}$ \\
\hline E3 or F3 & WUI 3 & $\begin{array}{l}\text { Exposed combustibles } \\
\text { are likely to ignite in } \\
\text { this area from high } \\
\text { ember flux or high } \\
\text { heat flux }\end{array}$ & $\begin{array}{l}\text { Intermediate Construction Hardening } \\
\text { Requirements: } \\
\text { - } \quad \text { No exposed combustibles on structure } \\
\text { - } \quad \text { Combustibles placed well away from } \\
\text { structure } \\
\text { - } \quad \text { Low flammability plants } \\
\text { - } \quad \text { Irrigated and well maintained landscaping } \\
\text { - } \quad \text { Local AHJ-Approved Access for } \\
\text { firefighting equipment }\end{array}$ \\
\hline $\mathrm{E} 4$ or $\mathrm{F} 4$ & WUI 4 & $\begin{array}{l}\text { Ignition of } \\
\text { combustibles from } \\
\text { direct flame contact is } \\
\text { likely. }\end{array}$ & $\begin{array}{l}\text { High Construction Hardening Requirements: } \\
\text { - } \quad \text { No exposed combustibles } \\
\text { - } \quad \text { All vents, opening must be closed } \\
\text { - Windows and doors must be covered } \\
\text { with insulated non-combustible } \\
\text { coverings. } \\
\text { - } \quad \text { Irrigated and well maintained low } \\
\text { flammability landscaping } \\
\text { - Local AHJ-Approved Access for } \\
\text { firefighting equipment }\end{array}$ \\
\hline
\end{tabular}




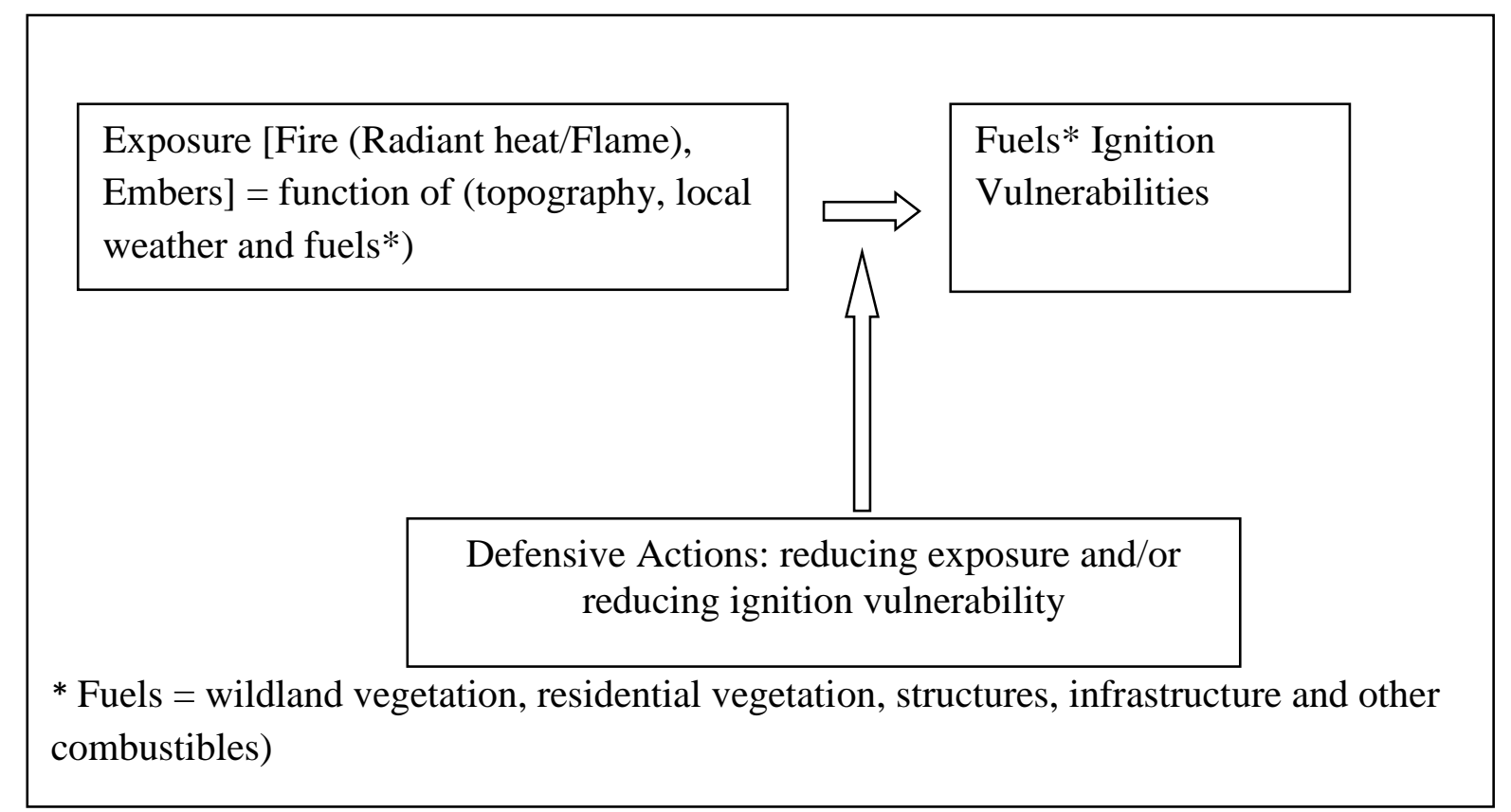

\section{Figure 7: Defensive Actions - reducing exposure and/or reducing ignition vulnerability}

Table 7 summarizes the fire and ember threats presented to homeowners and fire fighters. It should be noted that fire fighters are explicitly differentiated here from other first responders because of their fire resistive personnel protective equipment.

Table 5: Fire and Ember Exposures and Threat to Homeowners and Fire Fighters

\begin{tabular}{|l|l|l|}
\hline Fire Exposure Scale & Threat to Homeowners & Threat to Fire Fighters \\
\hline F1- None & None & None \\
\hline F2 - Low heat flux & Severe & None \\
\hline F3 - Moderate heat flux & Severe & Moderate \\
\hline $\begin{array}{l}\text { F4 - Severe heat flux } \\
\text { prolonged direct flame } \\
\text { contact) }\end{array}$ & Severe & Severe \\
\hline Ember Exposure Scale & \multicolumn{2}{|l|}{} \\
\hline E1 - None & None & None \\
\hline E2 - Minor & Moderate & None \\
\hline E3 - Significant & Severe & None \\
\hline E4- Extreme & Severe & None \\
\hline
\end{tabular}

\footnotetext{
${ }^{10}$ Fire fighters wearing appropriate Personal Protective Equipment (PPE).
} 


\subsection{Improving WUI Building Codes and Standards}

In order to successfully implement the exposure scale, building codes, standards, and best practices must be developed to address the fire and ember exposure as estimated by both the $\mathrm{E}$ and F-scales. Figure 6 illustrates the ember exposure - building construction coupling. While construction in the E-4 or F-4 zones is possible, in an attempt to provide cost effective solutions, focus is placed here on the zones where fire and ember exposure are not as extreme, namely E1 through E3 and F1 through F3.

\subsection{Special Implementation Considerations}

The landscaping issues in and around a community fall under the regulatory purview of land use planners and zoning officials. In organized subdivisions, these issues may also fall under the purview of an architectural review board. The proposed WUI-scale framework could be used to provide guidance on fuel treatments in and around existing or new communities. As an example, in order to reduce the ember exposure generated in E-4 zones, an option may exist to conduct fuel treatments around a particular community. To date, fuel treatment effectiveness has been evaluated primarily from an ecological perspective. There is, therefore, very little technical information on how to effectively "treat" wildland fuels in order to generate a known hazard reduction for the adjacent community. The Joint Fire Science Program (JFSP), US Department of Interior - Bureau of Land Management, 2011 Request for Applications ${ }^{\text {xiv }}$ was aimed at addressing this specific technical gap. There are many implementation challenges associated with fuel treatments such as jurisdictional issues, maintenance and environmental considerations. These are beyond the scope of this paper.

\subsection{Designing a New Community Using the WUI-Hazard Scale}

The first step in using the WUI-scale is to evaluate the exposure of a community from the fire in wildland fuels for the local topography and typical fire weather conditions. Once the wildland exposure has been determined, the next step may be the creation of fuel treatment zones if any are necessary and their implementation and maintenance are possible. Fuel treatment zones would be useful to consider any time E4 and/or F4 exposure levels are identified. This can be accomplished in one of two ways. An example is provided for an E-4 zone for illustrative purposes. The E-4 threat can be reduced by fuel treatment to decrease the area originally classified as E-4 or a fuel treatment zone can be created around the initial E-4 zone (see green area in figure 8). The fuel treated area can remain wildland or be adapted for use as common areas such as green spaces. The end result in both cases is the introduction of the buffer zone between the threat and the first built zone in order to attenuate the local ember exposure. Benefit-cost analysis tools are being developed by NIST's Engineering Laboratory specifically for this purpose ${ }^{\mathrm{xv}}$ These tools will enable community planners and land use administrators to weigh the benefits of long term wildland fuel treatments against the increased construction and maintenance requirements associated with a community exposed to the higher fire hazards from untreated wildland fuels. 


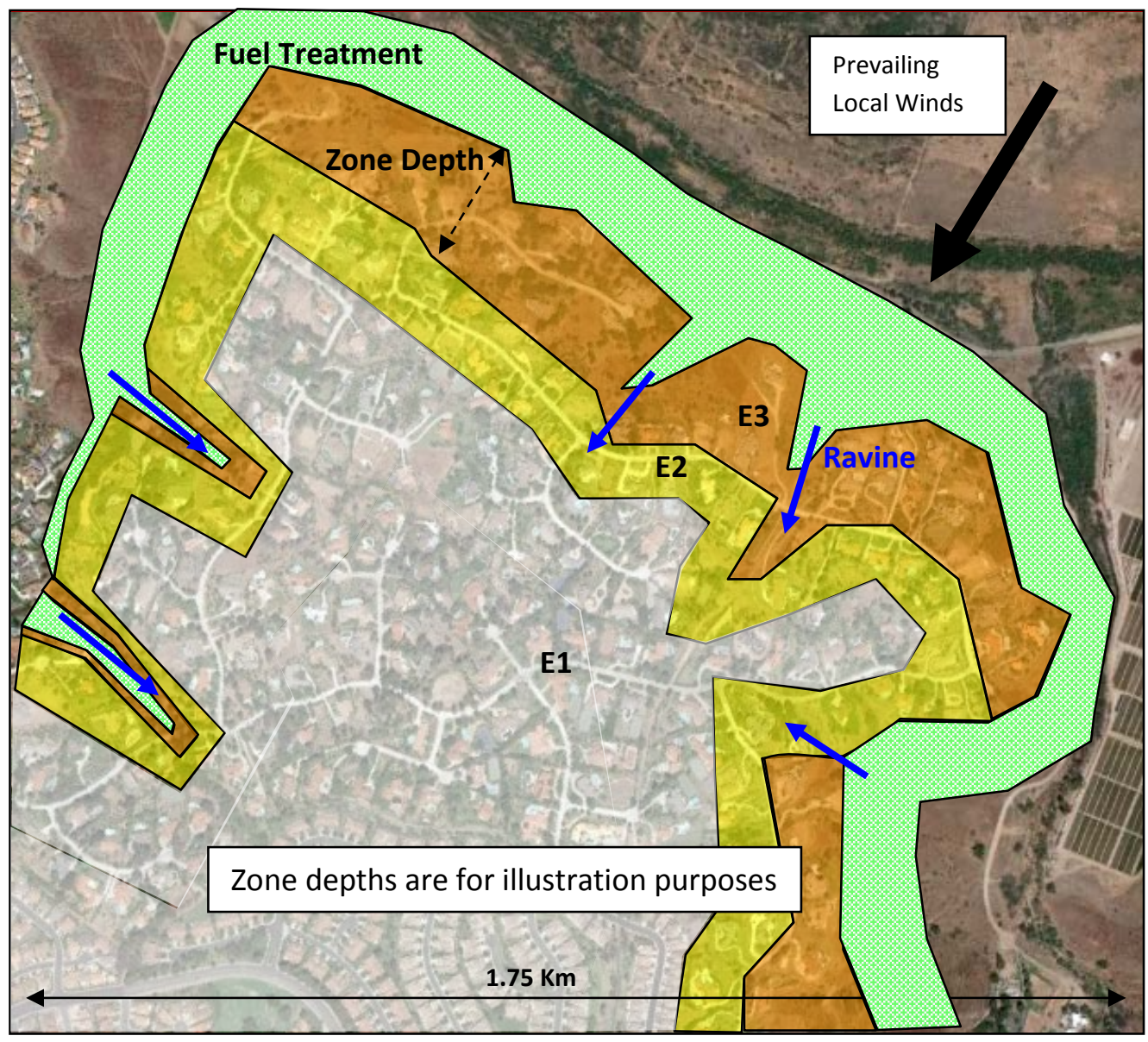

Figure 8: Illustration of wildland ember exposure on community surrounded fuel treatment

\subsection{Evaluating an Existing Community Using the WUl-hazard scale}

Existing communities could be evaluated using the WUI-hazard scale in order to assess vulnerabilities, potential losses from a WUI fire, and to focus retrofit efforts. The WUIscale evaluation of the community can also be used to assess the impact of wildland fuel treatments and how they can affect the retrofit requirements within the community.

Evaluating an existing community using the WUI-hazard scale is a two step process. The first step is to assess the community's level of fire and ember exposure from the wildlands based on the fuels, terrain, and local weather (FTLW). This evaluation will determine WUI-zones throughout and around the entire community. The second step is to collect construction and landscaping/vegetation attributes for the structures in the community and compare them to the recommendations associated with the different WUI-zones. This step will highlight vulnerabilities and identify areas where structures, given their existing construction and landscaping, will be more at risk. The WUI-zone concept is based on quantifying fire and ember exposure throughout an existing WUI community. If structure ignition vulnerabilities are not addressed, then the initial hazard zoning assessment will not be valid. If structures are at a significant risk of igniting 
during a WUI fire event, then a new assessment of fire and ember exposure should be conducted in the community.

\subsection{Post Fire Community Reconstruction/Rebuilding}

The WUI-scale can be used to guide reconstruction in communities that have been affected by a WUI fire. The reconstruction at the community scale will begin with a community evaluation. Post WUI fire data will be used to determine the likely evolution of the fire scenario and to quantify fire and ember exposure across the entire community. E/F-zones will be identified and reconstruction beyond E1 and F1 zones will be guided by the proposed improved multi-tier building construction codes system.

Future post fire reconstruction plans may be developed using guidelines similar to those used for rebuilding in flood prone areas, earthquake zones or other disaster prone areas. ${ }^{18}$ The WUI-scale will enable more sustainable rebuilding of WUI communities by integrating fire resistant structures and vegetation with community planning and design.

\subsection{Future Work}

The above framework outlines the fundamentals of the WUI-hazard scale methodology and how it can be used to improved building codes and standards. Table 7 summarizes the WUI-scale framework, including the $\mathrm{E}$ and F scale construction considerations and threats to homeowners and first responders. The four construction classes, WUI 1 through WUI 4 will enable targeted and cost effective hazard mitigation implementation. While the full characteristics and resulting ember fluxes for the different ember exposures are not currently known, initial values will be obtained by a combination of field and laboratory experiments, NIST and the US Forest Service (USFS) are working on conducting both types of experiments to provide initial ember and heat flux exposure values across a range of wildland fuels and weather conditions. Computer modeling will be used to augment the field and laboratory experiments for conditions that are not be evaluated experimentally. Figure 9 illustrates the proposed technical framework for developing the WUI-scale.

The work necessary to implement the proposed WUI-scale falls into three categories:

1. Develop building construction and landscaping guidance for the building and fire codes and standards. This work should be conducted in partnership with national and international standards and codes organizations. Emphasis will be given to design guidance and or requirements for both new construction and retrofit solutions of existing structures. The technical coupling of the exposure to construction requirements set forth in building codes and standards is one of the cornerstones of the proposed approach.

2. Create a guide for field application of the WUI-scale methodology in new and existing communities including application to retrofit and post fire reconstruction needs. This is important for two reasons. A field application guide will enable communities to assess their vulnerabilities and take proactive steps to reduce their 
WUI risks. The guide will aid for post fire reconstruction for communities affected by WUI fires.

3. Refine the guidance and expand the applications through research to better define fire and ember exposure levels based on fuel, topography and local weather. This is the technical foundation of the E/F-scale system. Work will be done with different wildland fuel types and fuel loadings. This work will be done with technical input from laboratory and field experiments as well as through the use of two and threedimensional fire models. The technical approach to the development of the E/F scale has four components:

- Post-fire data collections, such as conducted by NIST, ${ }^{\text {vi, xvi }}$ Texas Fire Service (TFS) and USFS. The post fire data collections is needed to identify construction and landscaping vulnerabilities as well as validate the performance of implemented hazard reduction technologies.

- Field data collections from prescribed burns are needed to quantify the fire and ember exposures for different fuel topography and local weather conditions.

- Laboratory work is needed to characterize the ignition response of structure materials and assemblies to exposures representative of real conditions. Guidance on representative exposure conditions and candidate structure vulnerabilities will be obtained from field data. Representative building constructions will be evaluated for all four building classes identified in Table 7. NIST has developed an ember generator that can be used to generate specific ember size and quantify distributions. The capabilities of this experimental apparatus have been demonstrated on initial experiments with roof assemblies, vents and decks. ${ }^{\text {xvii }}$ [What about collaborating work with IBHS?]

- Computer modeling using tools such as the NIST and USFS developed wildlandurban interface fire dynamics simulator (WFDS) ${ }^{\text {xviii }}$ will be initially used to create the zones. WFDS will be used to create simpler tools as technical expertise and model validation mature. Models will also be used to identify ignition threshold zones for the different types of construction and therefore yield the E3 though E1 and F3 though F1 zone boundaries. Representative buildings will be created in the model based on the laboratory experiments. An example of a WFDS calculation for an existing community is shown in Figure 10. 
Table 6: WUI-scale Framework Summary

\begin{tabular}{|c|c|c|c|c|c|c|}
\hline $\begin{array}{l}\text { E- } \\
\text { scale/zone }\end{array}$ & $\begin{array}{l}\text { Ember } \\
\text { Exposure }\end{array}$ & $\begin{array}{l}\text { Ember Flux } \\
\text { (grams/m²-sec) }\end{array}$ & $\begin{array}{l}\text { Building } \\
\text { Construction } \\
\text { Class } \\
\end{array}$ & $\begin{array}{l}\text { Building Construction } \\
\text { Attributes for Protection } \\
\text { against Embers }\end{array}$ & $\begin{array}{l}\text { Threat to } \\
\text { Homeowners }\end{array}$ & $\begin{array}{l}\text { Threat to Fire } \\
\text { Fighters }\end{array}$ \\
\hline E-1 & None & None & WUI 1 & $\begin{array}{ll}\text { Normal Construction Requirements } \\
\text { - } \quad \text { Maintained Landscaping } \\
\text { - } \quad \text { Local AHJ-Approved Access for firefighting } \\
\quad \text { equipment }\end{array}$ & No & No \\
\hline E-2 & Minor & $* *$ & WUI 2 & \begin{tabular}{ll}
\multicolumn{2}{l}{ Low Hardening Construction Requirements: } \\
- & Treated combustibles allowed on structure \\
- & Attached treated combustibles allowed \\
- & Treated combustibles allowed around structure \\
- & Low flammability plants \\
- & Irrigated and well maintained Landscaping \\
- & Local AHJ-Approved Access for firefighting \\
& equipment
\end{tabular} & Moderate & No \\
\hline E-3 & Significant & ** & WUI 3 & 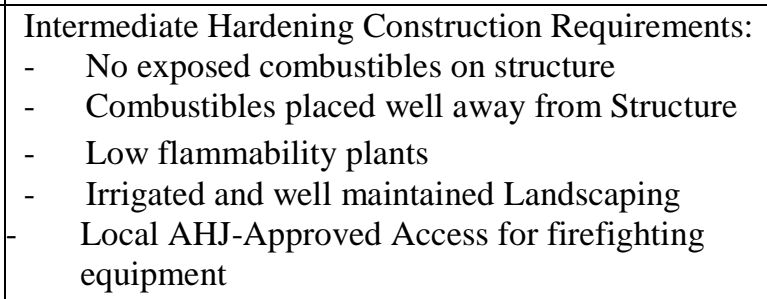 & Severe & No \\
\hline E-4 & Extreme & $* *$ & WUI 4 & \begin{tabular}{ll}
\multicolumn{2}{l}{ High Hardening Construction Requirements: } \\
- $\quad$ No exposed combustibles \\
- $\quad$ All vents, opening must be closed \\
- $\quad$ Windows and doors must be covered with \\
insulated non-combustible coverings. \\
- $\quad$ Irrigated and well maintained low \\
$\quad$ flammability landscaping - not \\
- $\quad$ Local AHJ-Approved Access for firefighting \\
$\quad$ equipment - not
\end{tabular} & Severe & No \\
\hline
\end{tabular}


WUI-scale Framework Summary (Continued)

\begin{tabular}{|c|c|c|c|c|c|c|}
\hline F-scale/zone & \begin{tabular}{|l} 
Fire \\
Exposure
\end{tabular} & $\begin{array}{l}\text { Heat Flux } \\
\left(\mathrm{W} / \mathrm{cm}^{2}\right)\end{array}$ & $\begin{array}{l}\text { Building } \\
\text { Construction } \\
\text { Class }\end{array}$ & $\begin{array}{l}\text { Building Construction } \\
\text { Attributes for Protection } \\
\text { against Fire }\end{array}$ & $\begin{array}{l}\text { Threat to } \\
\text { Homeowners }\end{array}$ & $\begin{array}{l}\text { Threat to Fire } \\
\text { Fighters }\end{array}$ \\
\hline F-1 & None & 0 & WUI 1 & $\begin{array}{ll}\text { Normal Construction Requirements } \\
\text { - } & \text { Maintained Landscaping } \\
\text { - } & \text { Local AHJ-Approved Access for firefighting } \\
& \text { equipment }\end{array}$ & No & No \\
\hline F-2 & $\begin{array}{l}\text { Low heat } \\
\text { flux** }\end{array}$ & $<0.8$ & WUI 2 & \begin{tabular}{ll}
\multicolumn{2}{l}{ Low Hardening Construction Requirements: } \\
- & Treated combustibles allowed on structure \\
- & Attached treated combustibles allowed \\
- & Treated combustibles allowed around structure \\
- & Low flammability plants \\
- & Irrigated and well maintained Landscaping \\
- & Local AHJ-Approved Access for firefighting \\
& equipment
\end{tabular} & Severe & No \\
\hline F-3 & $\begin{array}{l}\text { Moderate } \\
\text { heat flux** }\end{array}$ & $0.8-2$ & WUI 3 & $\begin{array}{ll}\text { Intermediate Hardening Construction Requirements: } \\
-\quad \text { No exposed combustibles on structure } \\
- & \text { Combustibles placed well away from Structure } \\
- & \text { Low flammability plants } \\
- & \text { Irrigated and well maintained Landscaping } \\
- & \text { Local AHJ-Approved Access for firefighting } \\
& \text { equipment }\end{array}$ & Severe & Moderate \\
\hline F-4 & $\begin{array}{l}\text { Severe heat } \\
\text { flux** } \\
\text { (prolonged } \\
\text { direct flame } \\
\text { contact) }\end{array}$ & $>2$ & WUI 4 & 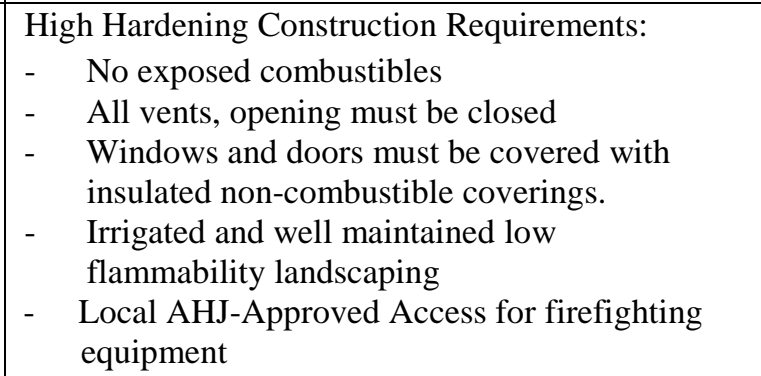 & Severe & Severe \\
\hline
\end{tabular}




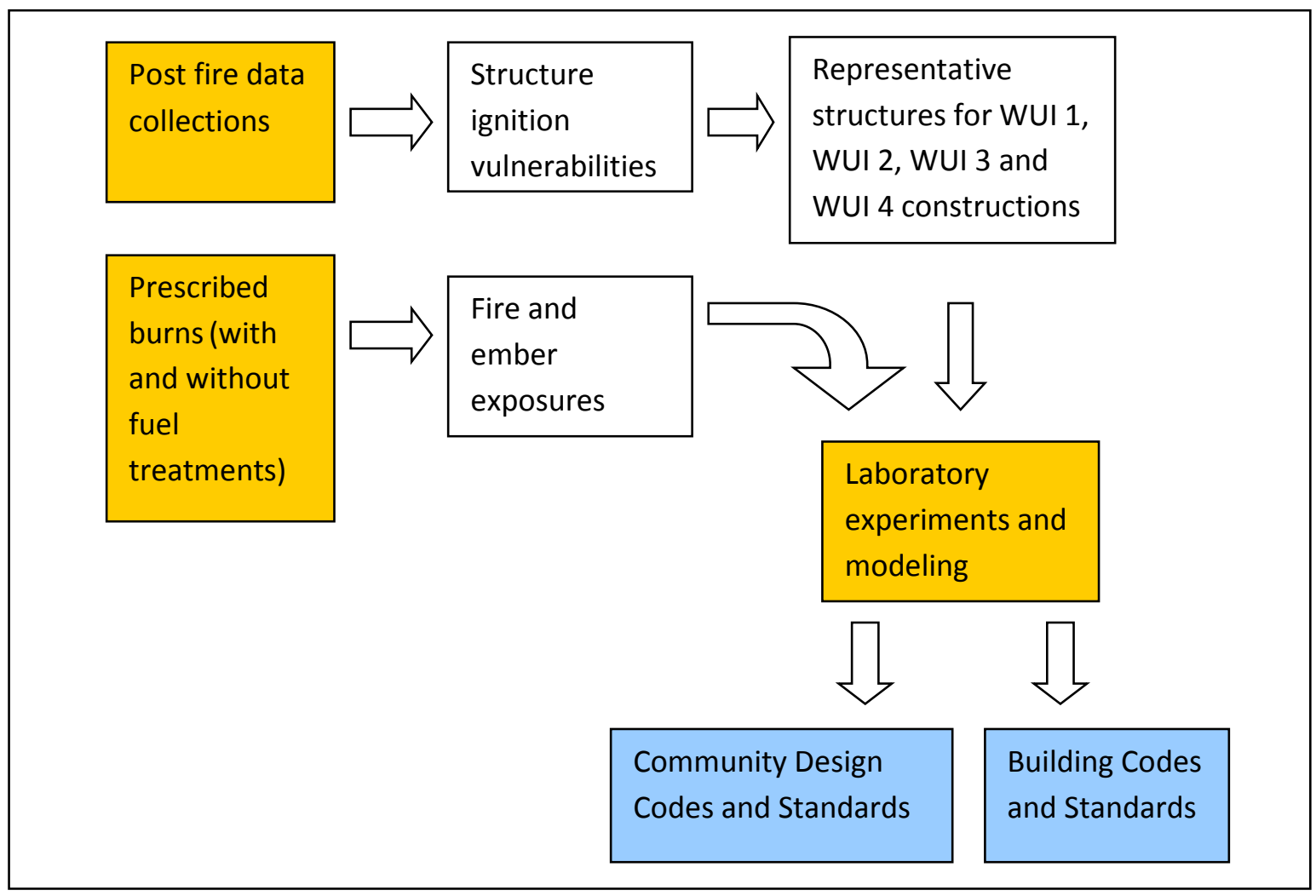

Figure 9: Technical framework for developing the WUI Hazard Scale ${ }^{11}$

\subsection{Conclusions}

The WUI-scale and zone concept offers a framework for evaluating the fire and ember exposure of proposed and existing WUI communities. The coupling of the WUI-hazard scale concept with a multi-tiered codes and standards framework will enable an efficient reduction in WUI structural losses for both new and existing communities. Additionally, the framework links fire and ember exposure and resident and fire fighter safety. While there is significant technical work that is necessary to fully implement the proposed framework, this coupled exposure-vulnerability technical approach could offer a datadriven cost effective way to reduce losses from future WUI fires.

A quantified and easily implemented exposure scale is needed. Without it, efforts to reduce the structural losses from WUI fire incidents will likely have only limited success. This paper has outlined the framework for the initial development of the WUI-hazard scale concept. Future research will guide further development of the concept for the effective implementation of the WUI-hazard scale/zone concept and WUI building construction class system.

\footnotetext{
${ }^{11}$ Prescribed burns will be conducted in different fuel, topographical and weather conditions.
} 


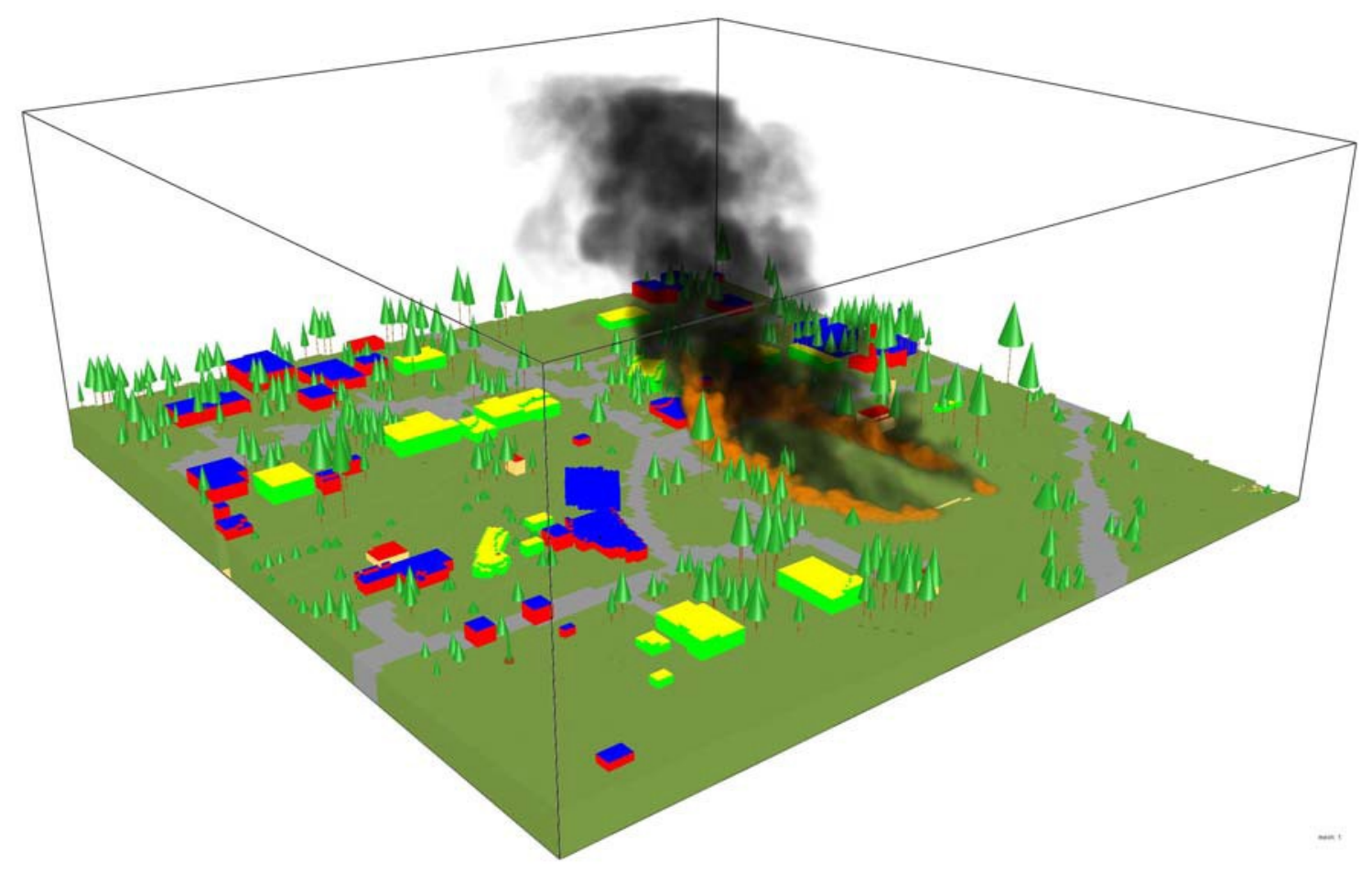

Figure 10: Snapshot from a computer simulation, using the Wildland-urban interface Fire Dynamics Simulator (WFDS), ${ }^{18}$ of a WUI fire in Worley, Idaho. Tree locations and heights were obtained from LiDAR data.

\subsection{Acknowledgments}

This work was made possible though technical collaboration with numerous organizations including but not limited to CAL FIRE, San Diego Building Codes Department, The International Code Council and the National Fire Protection Association. This work is in part funded by the Joint Fire Science Program Project 11-1-3-29, "Evaluating the Effectiveness of Mitigations Activities in the Wildland Urban Interface”. 


\subsection{References}

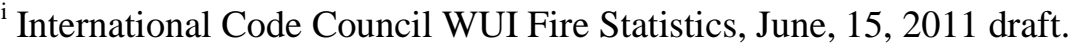

ii Technical discussion with Texas Forest Service, October 2011.

iii Paragraph Citation, 66 Federal Register 753, January 4, 2011

${ }^{\text {iv }}$ Fourmile Canyon Fire, Preliminary Findings, U.S. Department of Agriculture Forest Service Rocky Mountain Research Station, Revised October 12, 2011, http://www.fs.fed.us/rmrs/docs/fourmile-canyon-fire/preliminary-findings.pdf
}

${ }^{v}$ Mega Fires: The Case for Mitigation, Institute of Business and Home Safety, July 2008, http://www.disastersafety.org/content/data/file/megafires_full.pdf

${ }^{v i}$ A Case Study of a Community Affected by the Witch and Guejito Fires, Maranghides and Mell, Fire Technology, 47(2), April 2011, pp. 379-420.

vii California Wildland-Urban Interface Code Information, http://www.fire.ca.gov/fire_prevention/fire_prevention_wildland_codes.php

viii

http://www.fire.ca.gov/fire_prevention/downloads/ICC_2009_Ch7A_2007_rev_1Jan09 Supplement.pdf

ix Jack Cohen, http://www.firewise.org/Information/Research-and-Guidance/WUI-HomeIgnition- Research/The-Jack-Cohen-Files.aspx

${ }^{\mathrm{x}}$ International Code Council, International Wildland-Urban Interface Code, 2012.

xi The wildland-urban interface fire problem-current approaches and research needs, Mell, Manzello, Maranghides, Butry and Rehm,, International Journal of Wildland Fire 2010, 19, 238-251

xii Based on threshold window breakage values identified in NIST-GCR-98-751, Window Breakage Induced by Exterior Flames, Frederick W. Mower, June 1998.

xiii Buschman, A.J., “'Ignition of Some Woods Exposed to Low Level Thermal Radiation,’’ NBS Report 7306, Natl. Bur. Stand., Washington, DC, 1961.

xiv JFSP FY2011, Request for Applications, Area Of Interest 9: Fuel Treatments and the Wildland Urban Interface, http://www.firescience.gov/JFSP_AFPs.cfm

${ }^{\mathrm{xv}}$ Fighting Fire with Fire: estimating the efficacy of wildfire mitigation programs using propensity scores, Butry, Environmental and Ecological Statistics 16:291-319 (2009)

${ }^{x v i}$ Initial Reconnaissance of the 2011 Wildland-Urban Interfaces Fires in Amarillo, Texas, Maranghides, Mell, Ridenour, McNamara, NIST Technical Note 1708, June 2011. 
${ }^{x v i i}$ Manzello, S., Suzuki, H., "Summary of Full Scale Experiments to Determine Vulnerabilities of Building Components to Ignition by Firebrand Showers", NIST SP 1126, January, 2012.

xviii http://www.fs.fed.us/pnw/fera/research/wfds/ 